\title{
THE ROLE OF CENTRAL AND REGIONAL GOVERNMENTS IN THE RESOLUTION OF LAND PROBLEMS OF THE INDONESIAN NAVY AS A MILITARY TRAINING AREA IN GRATI PASURUAN
}

\author{
Uciek Darmayani ${ }^{1}$, Rr. Lilik Ekowati², Viv Djanat Prasita ${ }^{3}$ \\ Universitas Hang Tuah, Surabaya, Indonesia
}

\begin{abstract}
The Indonesian Navy owns land assets of State Property (BMN) in Grati, Pasuruan Regency covering an area of 36,763,350 $\mathrm{m}^{2}$ (3,676.34 Ha). In accordance with Government Regulation of the Republic of Indonesia Number 68 of 2014 concerning State Defense Territory Arrangement. There are 1,033 locations of Indonesian Forces lands that are included in the Territory The defense consists of the Indonesian Army as many as 583 locations, the Indonesian Navy as many as 93 locations and the Indonesian Air Force in 357 locations. The Defense Area consists of military bases or soldiers, military training areas, military installations, equipment testing areas, storage areas for other explosive and dangerous goods, areas for disposal of ammunition and other dangerous defense equipment, strategic national vital objects and air defense interests. the land of the Indonesian Navy BMN in Grati, Pasuruan Regency cannot be used optimally for the Indonesian Forces training area because many residents inhabit the Indonesian Navy land for agricultural land and housing so that the participation of the central and regional governments is needed in resolving these problems so that the Indonesian Navy can use the land as a training area in accordance with the Main Duties and Main Functions of the Indonesian Navy. And This research used descriptive qualitative methods and analysis is carried out based on the findings of the data that has been collected.
\end{abstract}

Keywords: Policy evaluation, military training area, community relocation, team formation combined

\section{INTRODUCTION}

The Unitary State of the Republic of Indonesia with the characteristics of an archipelagic country with the characteristics of an archipelago is a unitary container covering land, sea and air spaces, including space within the earth, with their contents. One of the efforts in area management with National Spatial Planning is very much needed for defense purposes. From the defense aspect, spatial planning is directly related to the national defense strategy, while Defense Territory Arrangement includes defense area planning, defense area utilization and defense area utilization control.

In accordance with the Government Regulation of the Republic of Indonesia Number 68 of 2014 concerning State Defense Territory Arrangement, the State Defense Territory, hereinafter referred to as the Defense Territory, is an area designated to defend the country's sovereignty, the territorial integrity of the Unitary State of the Republic of Indonesia and the safety of the entire nation from threats and disturbances to the integrity of the nation and country. In accordance with the Government Regulation of the Republic of Indonesia Number 68 of 2014 concerning the Arrangement of the State Defense Territory, there are 1,033 locations of TNI lands that are included in the Defense Territory, including the BMN TNI AL land in Grati, Pasuruan Regency used for Military Training Areas (TNI AD, TNI $A L$ and TNI AU).

The spatial planning of Pasuruan Regency is described in the Regional Spatial Plan (RTRW) of Pasuruan Regency which is stipulated by the Regional Regulation of Pasuruan Regency in accordance with Law No. 26 of 2007 concerning Spatial Planning. Pasuruan Regency Regional Regulation Number 12 of 2010 concerning RTRW of Pasuruan Regency 2009-2029 states that the National Strategic Area (KSN) is an area whose spatial planning is prioritized because it has an important national influence on state sovereignty, national defense and security, economy, social, culture and / or the environment. District National Strategic Area (KSNK) is an area where spatial planning is prioritized because it has an important influence on economic, social, cultural and / or environmental aspects.

The land of the Indonesian Navy in Grati, Pasuruan Regency is used as a TNI / Navy Training Area which is in the area of 2 Districts namely Lekok District and Nguling District and 10 Villages namely Alas Tlogo Village, Sumber 
Anyar Village, Gejugjati Village, Balung Anyar Village, Branang Village, Tampung Village, Pasinan Village, Wates Village, Semedusari Village and Jatirejo Village. In solving the land problems of the Indonesian Navy in Grati, Pasuruan Regency, it is necessary to have support from the Regional Government of Pasuruan Regency, the Regional Government of East Java Province and the Central Government to immediately carry out the relocation of residents who inhabit the TNI AL training ground.

\section{THEORETICAL BASIS}

Evaluation has an important role in policy performance, namely the extent to which needs, values and opportunities have been achieved through public action. Evaluation can be likened to appraisal, rating and assessment. William N. Dunn (2012) suggests that there are several criteria for evaluating public policies, namely effectiveness, efficiency, adequacy, leveling, responsiveness and accuracy and several functions of policy evaluation are:

a. Providing valid and reliable evaluations of policy performance;

b. Contributing to clarification and criticism of the values that underlie the selection of goals and targets;

c. Contribute to the application of other policy analysis methods, including problem formulation and recommendations

\section{RESEARCH METHODOLOGY}

This research is carried out using qualitative research, namely descriptive research to understand a phenomenon using analysis. In research, the theoretical basis is used as a basis so that the focus of research is in accordance with the facts in the field. In qualitative research, it has the following characteristics: (1) answering specific problems raised from the research context; (2) special problems in research (focus); (3) the focus studied is more on process than result; (4) examines a unique focus; (5) using a natural research setting; (6) humans as a key tool or instrument in data collection; (7) the research design is provisional; (8) did not put forward the previous hypothesis; (9) does not use the sample concept; (10) the informant is called an informant; (11) observation, interview and document analysis as the main techniques in data collection; (12) data is qualitative in nature; (13) inductive data analysis; (14) credibility, transferability, auditability, and confirmability in seeing the validity of the data; (15) data analysis and reporting are descriptive; and (16) a grounded theory (Moleong 2010: 8-13.

\section{RESULT AND DISCUSSION}

4.1 Realizing a military training area in accordance with Indonesian Government Regulation Number 68 of 2014 concerning State Defense Territory Arrangement

With an estimated increase in the number of people by $7 \%$ per year, it is estimated that the number of residents currently occupying the land of the Indonesian Navy in Grati, Pasuruan Regency has increased by 11,988 , to become 41,958 people. From the 2016 data collection, the number of houses located on the training ground in Grati, Pasuruan Regency is 9,086 units with 4,428 permanent units, 3,891 semi-permanent units and 767 non-permanent units.

The Indonesian Navy as the owner of the State Owned Property (BMN) land has made various efforts to stop the increase in the number of houses and agricultural land that use TNI AL land as a manifestation of the responsibilities and obligations of the Indonesian Navy in safeguarding BMN assets by always carrying out patrols, supervision and socialization. to residents who inhabit the land of the Indonesian Navy in Grati, Pasuruan Regency. In accordance with the Republic of Indonesia Government Regulation Number 27 of 2014 concerning State / Regional Property Management mandates the Property User (TNI $\mathrm{AL}$ ) to monitor, utilize, transfer, administer, maintain and secure State / Regional Property under its control to realize orderly management of goods State Owned (BMN) so that it can be used in accordance with the main tasks and functions of the user of the goods / work unit. Aspects of securing the assets of State Property as follows:

a. Administrative aspect is the administration of BMN in order to secure BMN assets from an administrative perspective in the form of administrative documents issued by the competent authority relating to the existence of BMN,

b. Physical aspects are safeguards that are implemented to prevent the decline in function of goods, decrease in the number of goods and loss of goods;

c. Legal aspects so that BMN is protected / protected from potential legal problems such as disputes, lawsuits or illegally transferring ownership to other parties.

Physical aspects are safeguards that are implemented to prevent the decline in function of goods, decrease in the number of goods and loss of goods.

The synchronization process of the two policies, namely Pasuruan Regency Regional 
Regulation Number 12 of 2010 concerning RTRW of Pasuruan Regency 2009-2029 and PP RI Number 68 of 2014 concerning State Defense Regional Arrangement must be completed immediately by the Regional Government of Pasuruan Regency so that the goal is to realize the TNI / AL TNI training area. in Grati, Pasuruan Regency in accordance with PP RI Number 68 of 2014 can be implemented optimally.

\subsection{Planning for the relocation program for residents who live in the TNI AL training ground}

According to Mustofa (2011) that the location and place of new relocation is an important factor in relocation planning because it greatly determines the ease of getting to business land, social networks, jobs, business fields, credit and market opportunities. Choosing a location that is the same as the previous area (the old place) in terms of environmental, socio-cultural and economic characteristics will make it more likely to carry out relocation and successful income selection so it is ideal if the new relocation site should be geographically close to the old place (original) for maintain established social networks and community ties.

In accordance with Law Number 26 of 2007 concerning Spatial Planning, the authority of the central government in implementing spatial planning includes, among others, regulation, guidance and supervision of the implementation of spatial planning for national, provincial, district / word areas as well as on the implementation of spatial planning for National Strategic Areas (KSN). , province and district / city. The land of the Indonesian Navy in Grati,
Pasuruan Regency is a training area for the TNI / TNI AL so it is included in the National Strategic Area because it has a very important influence nationally on state sovereignty (defense and security), therefore in resolving problems that exist in the land of the Indonesian Navy in Grati, Pasuruan Regency is the authority of the central government including the implementation of relocation of residents who occupy TNI AL land without permission from the Indonesian Navy,

In accordance with the Master Plan and the Spatial Plan for the TNI / Puslatpur TNI Training Area that in the planning of the Indonesian Navy for the location and place of relocation for residents who inhabit the land of the Indonesian Navy, it is a location that is $\mathbf{5 0 0}$ meters to $3 \mathrm{~km}$ from the current location where the residents are building houses. and managing agricultural land so that geographically the same as the old place (original) as well as environmental, sociocultural and economic characteristics are still the same so that it is easy to maintain social networks. The relocation area for residents will be equipped with public infrastructure and utilities in accordance with Law no. 1/2011 concerning Housing and Settlements.

In accordance with the data collection data on the population and the number of heads of households (KK) who occupy the land of the Indonesian Navy, there is an average population increase rate of $21 \%$ for 3 years or $7 \%$ each year and the increase in the number of heads of households is an average of $6 \%$ for 3 years. years or $2 \%$ annually, so that the increase in the number of people who occupy the land of the Indonesian Navy in Grati, Pasuruan Regency for 9 years from 2017 to 2025 is in accordance with Table 1.

Table 1. Assumption of Increase in Population Occupying Indonesian Navy Land in Grati, Pasuruan Regency

\begin{tabular}{|c|c|c|c|}
\hline NO. & YEAR & $\begin{array}{c}\text { SOUL } \\
\text { (increase of } 7 \% \text { annually) }\end{array}$ & $\begin{array}{c}\text { KK } \\
\text { (increase of } 2 \% \text { annually) }\end{array}$ \\
\hline 1. & 2013 & 24,705 & 9,069 \\
\hline 2. & 2016 & 29,970 & 9,625 \\
\hline 3. & 2017 & 32,067 & 9,817 \\
\hline 4. & 2018 & 34,311 & 10,013 \\
\hline 5. & 2019 & 36,712 & 10,213 \\
\hline 6. & 2020 & 39,281 & 10,417 \\
\hline & & & \\
\hline
\end{tabular}




\begin{tabular}{|c|c|c|c|}
\hline 7. & 2021 & 42,030 & 10,625 \\
\hline 8. & 2022 & 44,972 & 10,837 \\
\hline 9. & 2023 & 48,120 & 11,053 \\
\hline 10. & 2024 & 51,488 & 11,274 \\
\hline 11. & 2025 & 55,092 & 11,499 \\
\hline
\end{tabular}

Source: Processed by Researchers

The Indonesian Navy has made a Master Plan for a population relocation area of $2,740,300 \mathrm{~m} 2$ equipped with facilities, infrastructure and public utilities with details of land use as follows roads and waterways covering an area of $642,300 \mathrm{~m} 2$, land for public facilities covering an area of 598,000 m2 (10 Kindergarten / KB, 4 units of Elementary Schools, 1 unit of Junior High School (SLTP) and 5 units of Mosques / Mushola as well as a residential area of 1,500,000 m2.

The Ministry of Public Works and Public Housing (PUPR Ministry) continues to increase the construction of a number of Flats for LowIncome Communities (MBR) to be able to have livable houses as part of the One Million Houses Program. Efforts made by the government both in terms of provision and financing through a number of programs, in terms of provision, the Ministry of PUPR allocates a budget for the development program of Flats (Flats) for MBR.

The area of agricultural land will decrease so that the area of agricultural land that will be received by each household will be less and it will also have an impact on the welfare of the relocated residents because there will be less production from agricultural products. With the support for the provision and financing of flat development from the Ministry of PUPR, the number of type 36 houses and the number of apartment units to be built, the area of agricultural land that will be received by each household under the assumption up to 2025 is in accordance with Table 2.

Table 2. Land Use Analysis in accordance with Assumption of Increase in Number of Households

\begin{tabular}{|c|c|c|c|c|c|c|c|}
\hline No. & Year & $\begin{array}{c}\text { Facilities, } \\
\text { Area \& } \\
\text { Public } \\
\text { Utilities } \\
\text { (m2) }\end{array}$ & $\begin{array}{l}\text { Number of } \\
\text { households } \\
\text { that given } \\
\text { flat } \\
\text { (KK) }\end{array}$ & $\begin{array}{c}\text { Number } \\
\text { of Flats } \\
\text { (unit) }\end{array}$ & $\begin{array}{c}\text { Flat area } \\
(\mathrm{m} 2)\end{array}$ & $\begin{array}{l}\text { Agricultural land area } \\
\text { for each household } \\
\text { (m2) }\end{array}$ & $\begin{array}{l}\text { Compared with } \\
\text { the plan of the } \\
\text { Indonesian } \\
\text { Navy } \\
\text { (m2) }\end{array}$ \\
\hline 1 & 2 & 3 & 4 & 5 & 6 & 7 & 8 \\
\hline 1. & 2021 & 822,090 & $\begin{array}{c}10,880 \\
\text { (assuming } \\
\text { number of } \\
\text { households = } \\
10,625 \text { ) }\end{array}$ & 34 & $\begin{array}{l}\text { Number of houses } \\
\text { type } 36 \\
=34 \text { units } \times \text { ( } 80 \text { pcs } \\
\text { type } 36 \\
\times 4 \text { floors) } \\
=34 \text { units } \times 320 \text { pcs } \\
\text { type } 36 \\
=10,880 \text { pcs type } 36 \\
\text { Land for Flats with a } \\
\text { distance of } 10 \mathrm{~m} \\
\text { each } \\
=34 \text { units }(140 \mathrm{mx} 54 \\
\mathrm{m}) \\
=34 \text { units } \times 7,560 \mathrm{~m} 2 \\
=257,040 \mathrm{~m} 2\end{array}$ & $\begin{array}{l}\text { Total agricultural land } \\
\text { area } \\
=2,740,300-822,090 \\
-257,040 \\
=1,661,170 \mathrm{~m} 2 \\
\text { Agricultural land area } \\
\text { for each household } \\
=1,661,170 \mathrm{~m} 2: 10,880 \\
=152.7 \mathrm{~m} 2\end{array}$ & $\begin{array}{l}=152,7 \mathrm{~m} 2- \\
114 \mathrm{~m} 2 \\
=38.7 \mathrm{~m} 2 \\
\text { (wider) }\end{array}$ \\
\hline 2. & 2022 & 822,090 & $\begin{array}{c}10,880 \\
\text { (assuming } \\
\text { number of } \\
\text { households }= \\
10,837 \text { ) }\end{array}$ & 34 & $\begin{array}{l}\text { Number of houses } \\
\text { type } 36 \\
=34 \text { units } \times(80 \text { pcs } \\
\text { type } 36 \\
\times 4 \text { floors) } \\
=34 \text { units } \times 320 \text { pcs } \\
\text { type } 36\end{array}$ & $\begin{array}{l}\text { Total agricultural land } \\
\text { area } \\
=2,740,300-822,090 \\
-257,040 \\
=1,661,170 \mathrm{~m} 2\end{array}$ & $\begin{array}{l}=152,7 \mathrm{~m} 2- \\
114 \mathrm{~m} 2 \\
=38.7 \mathrm{~m} 2 \\
\text { (wider) }\end{array}$ \\
\hline
\end{tabular}




\begin{tabular}{|c|c|c|c|c|c|c|c|}
\hline & & & & & $\begin{array}{l}=10,880 \text { pcs type } 36 \\
\text { Land for Flats with a } \\
\text { distance of } 10 \mathrm{~m} \\
\text { each } \\
=34 \text { units }(140 \mathrm{~m} \times 54 \\
\mathrm{m}) \\
=34 \text { units } \times 7,560 \mathrm{~m} 2 \\
=257,040 \mathrm{~m} 2\end{array}$ & $\begin{array}{l}\text { Agricultural land area } \\
\text { for each household } \\
=1,661,170 \mathrm{~m} 2: 10,880 \\
=152.7 \mathrm{~m} 2\end{array}$ & \\
\hline 3. & 2023 & 822,090 & $\begin{array}{c}11,200 \\
\text { (assuming } \\
\text { number of } \\
\text { households = } \\
11,053)\end{array}$ & 35 & $\begin{array}{l}\text { Number of houses } \\
\text { type } 36 \\
=35 \text { units } \times(80 \mathrm{pcs} \\
\text { type } 36 \\
\times 4 \text { floors) } \\
=35 \text { units } \times 320 \mathrm{pcs} \\
\text { type } 36 \\
=11,200 \text { pcs type } 36 \\
\text { Land for Flats with a } \\
\text { distance of } 10 \mathrm{~m} \\
\text { each } \\
=35 \text { units }(140 \mathrm{~m} \times 54 \\
\mathrm{m}) \\
=35 \text { units } \times 7,560 \mathrm{~m} 2 \\
=264,600 \mathrm{~m} 2\end{array}$ & $\begin{array}{l}\text { Total agricultural land } \\
\text { area } \\
=2,740,300-822,090 \\
-264,600 \\
=1,653,610 \mathrm{~m} 2 \\
\text { Agricultural land area } \\
\text { for each household } \\
=1,653,610 \mathrm{~m} 2: 11,200 \\
=147.7 \mathrm{~m} 2\end{array}$ & $\begin{array}{l}=147.7 \mathrm{~m} 2- \\
114 \mathrm{~m} 2 \\
=33.7 \mathrm{~m} 2 \\
\text { (wider) }\end{array}$ \\
\hline 4. & 2024 & 822,090 & $\begin{array}{c}11,520 \\
\text { (assuming } \\
\text { number of } \\
\text { households = } \\
11,274)\end{array}$ & 36 & $\begin{array}{l}\text { Number of houses } \\
\text { type } 36 \\
=36 \text { units } \times(80 \text { pcs } \\
\text { type } 36 \\
\times 4 \text { floors) } \\
=36 \text { units } \times 320 \text { pcs } \\
\text { type } 36 \\
=11,520 \text { pcs type } 36\end{array}$ & $\begin{array}{l}\text { Total agricultural land } \\
\text { area } \\
=2,740,300-822,090 \\
-272,160 \\
=1,646,050 \mathrm{~m} 2\end{array}$ & $\begin{array}{l}=142.9 \mathrm{~m} 2- \\
114 \mathrm{~m} 2 \\
=28.9 \mathrm{~m} 2 \\
\text { (wider) }\end{array}$ \\
\hline \multirow[t]{2}{*}{1} & 2 & 3 & 4 & 5 & 6 & 7 & 8 \\
\hline & & & & & $\begin{array}{l}\text { Land for Flats with a } \\
\text { distance of } 10 \mathrm{~m} \\
\text { each } \\
=36 \text { units }(140 \mathrm{~m} \times 54 \\
\mathrm{m}) \\
=36 \text { units } \times 7,560 \mathrm{~m} 2 \\
=272,160 \mathrm{~m} 2\end{array}$ & $\begin{array}{l}\text { Agricultural land area } \\
\text { for each household } \\
=1,646,050 \mathrm{~m} 2: 11,520 \\
=142.9 \mathrm{~m} 2\end{array}$ & \\
\hline 5. & 2025 & 822,090 & $\begin{array}{c}11,520 \\
\text { (assuming } \\
\text { number of } \\
\text { households = } \\
11,499)\end{array}$ & 36 & $\begin{array}{l}\text { Number of houses } \\
\text { type } 36 \\
=36 \text { units } \times(80 \mathrm{pcs} \\
\text { type } 36 \\
\times 4 \text { floors) } \\
=36 \text { units } \times 320 \mathrm{pcs} \\
\text { type } 36 \\
=11,520 \text { pcs type } 36 \\
\text { Land for Flats with a } \\
\text { distance of } 10 \mathrm{~m} \\
\text { each } \\
=36 \text { units }(140 \mathrm{~m} \times 54 \\
\mathrm{m}) \\
=36 \text { units } \times 7,560 \mathrm{~m} 2 \\
=272,160 \mathrm{~m} 2\end{array}$ & $\begin{array}{l}\text { Total agricultural land } \\
\text { area } \\
=2,740,300-822,090 \\
-272,160 \\
=1,646,050 \mathrm{~m} 2 \\
\text { Agricultural land area } \\
\text { for each household } \\
=1,646,050 \mathrm{~m} 2: 11,520 \\
=142.9 \mathrm{~m} 2\end{array}$ & $\begin{array}{l}=142.9 \mathrm{~m} 2- \\
114 \mathrm{~m} 2 \\
=28.9 \mathrm{~m} 2 \\
\text { (wider) }\end{array}$ \\
\hline
\end{tabular}

\section{Source: Processed by Researchers}

4.3 Budget support from the Central Government in solving problems

In accordance with Law Number 26 of 2007 concerning Spatial Planning, the authority for spatial planning for the National Defense
Forces defense and security sector is the central government so that budget support is also the responsibility of the central government so that the budget that supports the planning process up to the implementation of relocation 
of residents who inhabit TNI land The Navy to the population relocation area that has been prepared by the Indonesian Navy on the land of the Indonesian Navy in Grati, Pasuruan Regency, comes from the State Budget (APBN) proposed by each Ministry in accordance with its duties and responsibilities.

In accordance with the Law of the Republic of Indonesia Number 39 of 2008 concerning State Ministries that the State Ministry has several duties and responsibilities in accordance with their fields, there are several ministries involved in implementing the relocation of residents who inhabit the land of the Indonesian Navy in Grati, Malang Regency, namely: Ministry of Defense, Ministry of Politics, Law and Security, Ministry of Home Affairs, Ministry of Public Works and Public Housing (PUPR), Ministry of Agrarian Affairs and Spatial Planning and Ministry of Finance.

\subsection{Establishment of a Joint Team from the Relevant Ministries by the Government}

According to Law Number 26 of 2007 concerning Spatial Planning, the authority in spatial planning for the National Strategic Area (KSN) in the field of defense and security is the central government so that the central government is tasked with forming a joint team consisting of all Ministries involved in implementing the relocation of residents who occupy TNI AL land to the population relocation area that has been prepared by the Indonesian Navy. The joint team was formed which aims to build integrity, openness, cooperation and public accountability in the implementation of community relocation so that the relocation of residents who occupy the training area to the population relocation area can be successful in accordance with its implementation objectives.

Before forming a joint team consisting of all related Ministries, it is necessary to make a legal basis for the implementation of relocation of residents who occupy training areas for the TNI / Navy in the form of a Government Regulation. Government Regulation (abbreviated as PP) is the Laws and Regulations in Indonesia that are set by the President to implement laws. In accordance with Republic of Indonesia Law Number 12 of 2011 concerning the Formation of Legislation, it is stated that Government Regulations are organic rules rather than laws according to its hierarchy so that they cannot overlap or conflict. According to A. Hamid S Attamimi (1990), limiting laws and regulations are state regulations at the central level and at the regional level, which are formed based on statutory authority, both attributable and delegative in nature. Attamimi also stated that all legal rules established by all levels of institutions are in a certain form with certain procedures, usually accompanied by witnesses and are generally applicable and binding on the people. In accordance with Article 5 paragraph (2) and Article 22 of Law Number 12 Year 2011 concerning the Formation of Laws and Regulations, state institutions are authorized to form laws and regulations based on the attribution of power in the 1945 Constitution in forming Government Regulations (PP) and Regulations. The government in lieu of law (Perpu) is the President.

\section{CONCLUSIONS AND SUGGESTIONS}

\subsection{Conclusion}

The participation of the Central and Regional Governments in resolving the land problems of the Indonesian Navy as a military training area in Grati, Pasuruan Regency as discussed, can be concluded as follows:

a. State Defense Territory Arrangement In accordance with PP RI Number 68 of 2014 using William N. Dunn's theory (2003) which includes effectiveness, efficiency, sufficiency, leveling, responsiveness and overall accuracy is not optimal because the Indonesian Navy as the owner of the land has not been able to use the land for training in accordance with the Tupoksi TNI In addition, the synchronization process between the two laws and regulations will be completed immediately in accordance with Government Regulation No. 68/2014.

b. Planning for the relocation program for residents who inhabit TNI AL land in Grati, Pasuruan Regency must be carried out immediately because the number of residents living in the TNI AL training area is increasing so that the TNI / TNI AL is increasingly unable to use the training ground optimally.

c. There is budget support from the planning process to the implementation of the relocation of citizens from the State Budget (APBN) proposed by each Ministry in accordance with their duties and responsibilities.

d. The central government forms a joint team consisting of all Ministries involved in the implementation of citizen relocation which aims to build integrity, openness, cooperation and public accountability in the implementation of citizen relocation so that the implementation of citizen relocation can be successful in accordance with its implementation objectives by first making the legal basis for implementing relocation citizens in the form of Government Regulations (PP) or Government Regulations in Lieu of Law (PERPU). 


\section{2}

\section{Suggestion}

Based on these discussions and conclusions, the suggestions that can be given as material for consideration and input for the Indonesian Navy, the Pasuruan Regency Government and for the purposes of further research are as follows:

a. The Pasuruan Regency Government has just implemented the process of revising the Pasuruan Regency Regulation No. 12/2010 in 2020 so it is necessary to immediately complete the revision process in accordance with PP RI Number 68 of 2014 concerning State Defense Territory Arrangement.

b. The Indonesian Navy and the Pasuruan Regency Government jointly carried out data collection on the number of residents (Head of Families) of residents who inhabit the Indonesian Navy land in Grati, Pasuruan Regency because the last data collection was carried out in 2016.

c. The Indonesian Navy immediately submitted a request for the issuance of a Government Regulation (PP) or Regulation in Lieu of a Law (Perpu) as the basis for the formation of the Interdep Team.

d. The government immediately formed an Interdep Team consisting of all relevant ministries to solve problems on the land of the Indonesian Navy in Grati, Pasuruan Regency by carrying out the relocation of residents who inhabit TNI AL land to the population relocation area so that the TNI / TNI AL can use the land as an optimal training area.

e. Arranging the relocation area for residents according to the location in the Indonesian Navy Training Area Spatial Plan and Master Plan with the construction of 34 apartment units (4 floors with 80 Type 36 houses per floor) equipped with infrastructure (KB / TK School, SD, SMP, health facilities and mosques) and public utilities (drains).

f. The implementation of the relocation program needs to be carried out immediately by the government because the number of heads of families who occupy the TNI AL training area is increasing over time which will affect the area of agricultural land and the number of flats that need to be built.

g. The Indonesian Navy coordinated with the Regional Government of Pasuruan Regency (Bappeda) regarding the Revised Spatial Plan for the Pasuruan Regency RTRW for military areas on the land of the Indonesian Navy in Grati, Pasuruan Regency as follows:

1) The area of land for the military area listed in the Revised Spatial Plan for the RTRW of Pasuruan Regency is $4,109.31 \mathrm{Ha} \quad(41,093,100 \mathrm{~m} 2)$, however, it corresponds to 14
Certificate of Use Rights (SHP) in the name of the Department of Defense cq TNI AL covering an area of $3,676.34$ $\mathrm{Ha}$.

2) Including a community relocation area of 2,740,300 $\mathrm{m} 2$ in the Pasuruan Regency RTRW Revised Spatial Plan because it is used as a basis by the Ministry of Finance to carry out the elimination of BMN land assets belonging to the Navy.

\section{ACKNOWLEDGEMENT}

The authors greatly acknowledge the support from Hang Tuah University Surabaya Indonesia for providing the necessary resources to carry out this research work. The authors are also grateful to Hang Tuah University, UHT Surabaya, Indonesia who always give me opportunity to improve my research. And the last the authors would like to say thank to the anonymous reviewers and journal editorial board for their many insightful comments, which have significantly improved this article.

\section{REFERENCES}

Anderson James E. (1979: 67), Pulic Policy Making, New York: Holt, Rinehart and Winston.

Burhan Bungin, HM, March 2010, Qualitative Research, Communication, Economics of Public Policy, and Other Social Sciences, Fajar Interprama Offset, Jakarta.

Budi Winarni, MA, 2007, Public Policy, Theory and Process, Jakarta: Media Prosindo.

Dunn, William N, March 2003, Introduction to Public Policy Analysis, Second Edition, Gajah Mada University Press, Yogyakarta.

Dunn, N W. 2005, Introduction to Public Policy Analysis Second Edition, Yogyakarta: Gadjah Mada University Press.

Dwi Soesilawati (2013), Thesis Evaluation of the Implementation of Kasal Skep Number Skep / 344 / II / 2003 dated February 24, 2003 concerning Basic Regulations for Housing of the Indonesian Navy Service (Case Study in the Kelapa Gading, Ciangsana and Pasir Angin) Navy Complex. Faculty of Social and Political Sciences, Hang Tuah University. 
Dye, R. Thomas, 2002. Understanding Public Police - Tenth Edition. American.

Dye, Thomas R. 1987. Understanding Public Policy. USA: Prentice- Hall, INC., Englewood Cliffs, NJ.

Ekowati, Mas Roro Lilik, 2018, Policy or Program Implementation \& Evaluation Planning (A Theoretical and Practical Study), CV Litera Media Center, Surabaya.

Hayat, 2018, Public Policy: Evaluation, Reform, and Formulation, Intrans Publishing, Malang.

Mahan, A. T, 1971, The influence of the sea Power Upon History, Translation of Education and Training of the Indonesian Navy, Jakarta.

Matthew B.Miles \& A.Michael Huberman, 1992, Qualitative Data Analysis: A Resource Book About New Methods, UI-Press, Jakarta.

Moeheriono, 2012, Planning, Application and Development of Business and Public Main Performance Indicators (IKU), Rajawali Pers, Jakarta.

Moleong, Lexy. J, 2011. Qualitative Research Methodology. Bandung.
Rohindi, Tjetjep, 1992, Qualitative Data Analysis: A Resource Book About New Methods Matthew B. Miles \& A. Michael Huberman, UI-Press, Jakarta.

Sukmadinata, 2009. Research Methodology, Bandung: PT. Rosdakarya youth.

Sugiyono, 2005. Understanding Qualitative Research. Bandung: ALFABETA.

Subarsono, AG, 2005. Public Policy Analysis, Concepts, Theory, and Applications. Yogyakarta: Student Library.

Siswadi, E. 2012. Future Bureaucracy Towards Effective and Prime Government Governance, Bandung: Mutiara Press.

Wahab, Solichin Abdul, 2012, Policy Analysis from Formulation to Formulation of Public Policy Implementation Models, Bumi Aksara, Jakarta. 